\title{
Fine Structure of Gust Fronts Obtained from the Analysis of Single Doppler Radar Data
}

\author{
By Hiroshi Uyeda \\ Department of Geophysics, Faculty of Science, \\ Hokkaido University, Sapporo 060, Japan \\ and \\ Dusan S. Zrnic' \\ NOAA/ERL, National Severe Storms Laboratory, \\ 1313 Halley Circle, Norman, OK 73069, U.S.A. \\ (Manuscript received 18 December 1987, in revised form 26 September 1988)
}

\begin{abstract}
Doppler velocity data obtained from a single Doppler radar are used to examine fine structures of gust fronts associated with severe thunderstorms. Fields of inflection points of velocities (on surfaces scanned by a radar) are analyzed and are compared with the fields of spectrum width of Doppler velocity and horizontal shear. The analysis is performed on the cases of May 9, 1981 and April 13, 1981 in Oklahoma. In the first case, a gust front consisted of an evolving undulate bore with three separate waves or discontinuities. Two of these waves are detected as a $60 \mathrm{~km}$ stretch of inflection points of Doppler velocity, whereas the third is marginally evident. F'or both cases, the length representing secondary features behind the main discontinuities are short (less than $20 \mathrm{~km}$ ) and transient. Careful examinations of the structures at low altitude show that large spectrum width and large shear areas exist slightly behind the main line of inflection points. However, there is a multitude of areas with large shear and spectrum width that have no corresponding inflection point lines. Thus, these two parameters, spectrum width and horizontal shear, alone are not suitable for detection of gust fronts. Besides showing the presence of gust fronts, inflection points can also be good indicators of atmospheric waves. We discuss a pattern of such waves that are embedded in the environmental flow ahead of a gust front.
\end{abstract}

\section{Introduction}

A thunderstorm gust front is the leading edge of the horizontal airflow (outflow) resulting from a downdraft. The airflow produces horizontal speeds sometimes exceeding $25 \mathrm{~m} \cdot \mathrm{s}^{-1}$ behind the gust front; on occasions, the airspeed approaches twice this value and becomes extremely destructive. Increase of the knowledge about detailed structures of guest fronts is needed to understand low altitude wind shears. (c) 1988, Meteorological Society of Japan
Gust fronts have been known to produce atmospheric waves (Fulton and Zrnic', 1986) and there have been instances where multiple surges of gravity current had occurred. Such complicated systems did not lend themselves to easy observations until the advent of Doppler radars (Doviak and Zrnic', 1984).

The vertical structure and horizontal propagation of the gust front is analyzed by Charba (1974) and Guff et al. (1975) from wind and temperature data recorded on $450 \mathrm{~m}$ TV tower in Oklahoma City. They deduced that gust fronts 
consist primarily of a head of gravity current whose general structure resembles the outflows generated in a laboratory tank apparatus as shown by Simpson (1969), Simpson and Britter (1980) and others. The outflows are known to trigger successive convective cells in multicellular storms (e.g., Wilhelmson and Chen, 1982; Miller and Fankhauser, 1983; Peterson, 1984). Also an understanding of the interaction of a gust front with a dryline, a cold front, a seabreeze front, or another gust front is important in determining when and where convective clouds are likely to form (Holle and Maier, 1980; Purdom, 1982; Weaver and Nelson, 1982; Droegemeier and Wilhelmson, 1985a, b).

In order to understand the evolution of outflows and related phenomena, observations of gust fronts with fine temporal and spatial resolutions are needed. Recent study for Mueller and Carbone (1987) with multiple Doppler radar and surface mesonet revealed very detailed structures of the outflow. However, their analysis area of multiple Doppler radar was limited. For the study of wide spreading gust fronts and for the detection of the fronts on a real-time basis, observations with a single Doppler radar are considered to be valuable because of its large observation coverage. Analysis methods based on single Doppler radar data are expected to provide required details as the displays of Doppler spectral moments demonstrated that gust fronts produce characteristic signatures which human observers can interpret (Zrnic' and Lee, 1983).

Based on Doppler radar observations, Klingle (1985) made a case studies handbook of gust fronts. Paying attention to gust front's signatures, Uyeda and Zrnic' (1986) developed a method of automatic detection of gust fronts with a single Doppler radar. They showed that the method is effective and applicable to the detection of gust fronts for real time operation. Their analysis showed complicated horizontal undulations which nevertheless could be smoothed to produce useful forecasts of the future position. The undulations suggest existence of complicated small scale evolution of waves. Such fine structures may be isolated by analyzing maxima of the gradients of radial velocities, the so-called inflection points.
In this paper, the distribution of inflection points of velocities extracted along each radial is analyzed together with the Doppler spectrum width and the magnitude of quasi-horizontal shear. Here quasi-horizontal shear refers to the two-dimensional magnitude of radial velocity shear which is composed of azimuthal and radial components. Because this shear at low elevation angles is almost equal to the true horizontal shear, the adjective 'quasi' will be dropped in the sequel. Our analysis reveals waves in the environment and complicated patterns at and behind the thunderstorm outflow. Fine structures are compared to the vertical structure of gust fronts proposed by others.

\section{Methods of Analysis}

\subsection{Data}

The data used for this study are provided from the Norman Doppler radar of the National Severe Storms Laboratory. As the radar is situated in the middle of Oklahoma, the observed gust fronts are representative of those found in the Great Plains of the U.S.A. The radar wavelength is $10 \mathrm{~cm}$ and observations were made to a range of $100 \mathrm{~km}$. The gust front cases, April 13 and May 9, 1981 were selected for analysis, because these two showed significant fine structures (Uyeda and Zrnic', 1986). Three volume scans (at 0006, 0018 and 0032 CST) of the May 9, 1981 data are examined, and four volume scans (at 2111, 2116, 2123, 2128 CST) of the April 13, 1981 are examined. Both of these gust fronts were approaching the radar at the time of data collection.

\subsection{Radial processing}

Processing of one or two radials of radar data was done in order to preserve the inherent resolution of the instrument. The data were spaced by 150 or $200 \mathrm{~m}$ in range. Because the unambiguous velocity of the radar (34 or 26 $\mathrm{m} \cdot \mathrm{s}^{-1}$ ) was occasionally exceeded, it was necessary to de-alias the data using a combination of continuity and filtering as done by Uyeda and Zrnic' (1986).

\subsection{Analysis}

The analyzed data are reflectivity, radial component of velocity, spectrum width, hori- 
zontal shear, and inflection points (e.g., maxima of radial velocity gradients). The first three of these were read directly from the original data set. For the extraction of inflection points, nine points averaged (after de-aliasing) radial velocity was used. Horizontal shear was also calculated from the averaged radial velocities. Following the accepted convetion that winds away from the radar are positive and towards the radar are negative, it can be deduced that a decrease of velocity with range corresponds to convergence when the beam is close to the ground. Similarly, increasing velocity corresponds to divergence. This reasoning is strictly true only if there is no divergent/convergent flow perpendicular to the beam. Such situations approximately hold whenever the gust front is perpendicular to the radar beam. A schematic explanation of the relation between radial velocity profile and convergence/ divergence with associated up and down drafts is shown in Fig. 1. For example, decreasing velocity indicates convergence and updraft is expected there.

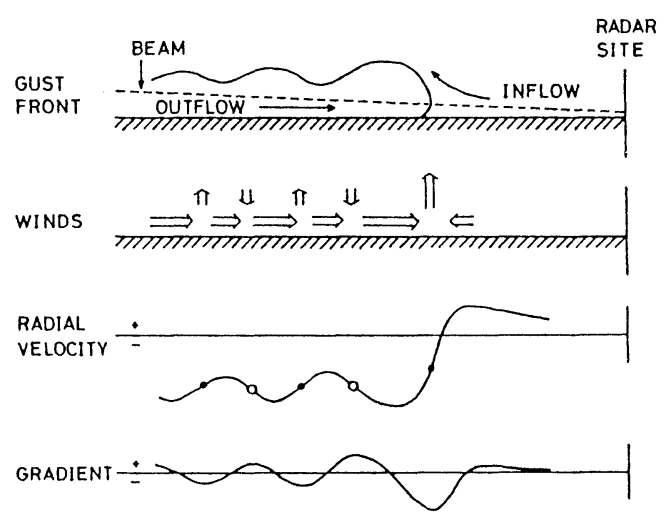

Fig. 1. Relation between horizontal and vertical winds through and in the vicinity of a gust front and radial velocity, gradient of radial velocity and inflection points of the velocity. Inflection points of decreasing and increasing velocities (namely, convergence and divergence) are shown by solid and open circles respectively on the graph of velocity.

Uyeda and Zrnic' (1986) located the position of a gust front at a maximum gradient point along a radial. It had a larger value of gradient than a certain threshold within a decreasing velocity range. Azimuthal link of these points reproduced the horizontal shape of the detected gust front. Because of filtering and high thresholds $\left(5 \mathrm{~m} \cdot \mathrm{s}^{-1} \cdot \mathrm{km}^{-1}\right)$ of radial, gradients only significant fronts were detected; small structures and secondary features of fronts were suppressed.

In contrast to this, present analysis uses a lower radial gradient threshold $\left(2 \mathrm{~m} \cdot \mathrm{s}^{-1} \cdot \mathrm{km}^{-1}\right)$ and reveals many inflection points along a radial. The extracted inflection points for decreasing and increasing velocities are plotted on surfaces scanned by the radar beam.

In order to examine the radial and azimuthal shear simultaneously we introduce horizontal shear (HS) defined as:

$$
H S=\left[\left(\frac{V A_{i+1}-V A_{i}}{R_{i+1}-R_{i}}\right)^{2}+\left(\frac{V A_{i}-V B_{i}}{R_{i} \tan \theta}\right)^{2}\right]^{1 / 2}
$$

where, $V A_{i}$ is the velocity component at a radial range $R_{i} . V B_{i}$ is the velocity component in the adjacent radial at the same range. Azimuthal separation between these radials is $\theta$, which varied from $0.5^{\circ}$ to $1.0^{\circ}$. Averaged radial velocities are used for calculating $H S$.

The field of horizontal shear is compared with the field of maximum gradients (inflection points) and with the Doppler spectrum width field in order to examine to what extent these fields offer complimentary information about the gust front. Our motivation is to determine whether better detection of the front is possible and if additional quantitative information about its structure and the environment into which it is propagating can be obtained.

Low altitude wind ahead of gust fronts was obtained from the velocity azimuth display (VAD, Browning and Wexler, 1968) analysis of a sector about $90^{\circ}$ wide. Data were carefully examined and discarded if they contained point targets, ground clutter, or had a low signal-tonoise ratio $(<0.0 \mathrm{~dB})$. Edited data from equal ranges were then regressed to best fit sinusoidal variations of radial velocities in azimuth.

\section{Results}

\subsection{Gust front of May 9, 1981}

\subsubsection{Dual structure of the front}

The guest front of May 9, 1981 detected by using the automatic detection algorithm of gust 
fronts proposed by Uyeda and Zrnic' (1986) is shown in Fig. 2. It is seen that the gust front propagated toward the radar and that a major undulation (from $280^{\circ}$ to $315^{\circ}$ ) remained coherent for over 15 minutes.

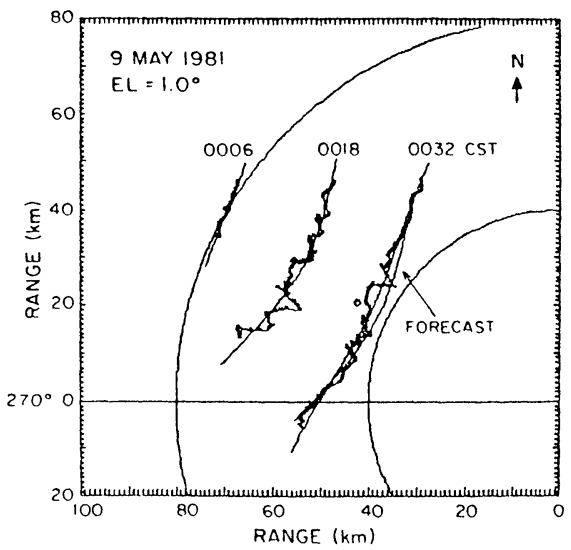

Fig. 2. Three consecutive positions of the front on May 9, 1981. The smooth curves are least square fits to data, and the forecast line is indicated for 0032 CST. (Uyeda and Zrnic', 1986).

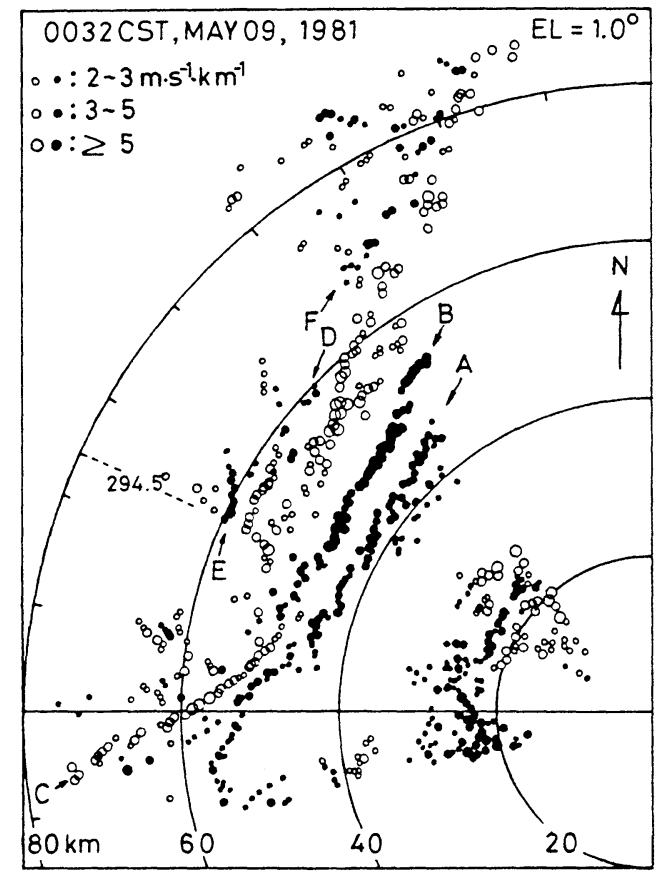

Fig. 3. Maxima of radial convergence $(\bullet)$ and divergence (o) at 0032 CST, May 9, 1981. The elevation angle is $1.0^{\circ}$. Azimuths of West and North are taken as $270^{\circ}$ and $360^{\circ}$ respectively. Magnitudes of velocity gradient at the inflection points are shown by the size of the circles for $2-3,3-5$ and $\geq 5 \mathrm{~m} \cdot \mathrm{s}^{-1} \cdot \mathrm{km}^{-1}$
In order to examine the precise structure of this feature, inflection points of 0032 CST at the elevation angle of $1.0^{\circ}$ are plotted in Fig. 3; only maxima of gradients larger than $2 \mathrm{~m} \cdot \mathrm{s}^{-1} \cdot \mathrm{km}^{-1}$ are shown. Two parallel lines of convergent inflection points ( $\mathrm{A}$ and $\mathrm{B}$ ) are prominent at the range of $41.43 \mathrm{~km}$ and $46-51 \mathrm{~km}$ between the azimuth of $285^{\circ}-330^{\circ}$. Line B has generally larger velocity gradients than line A. At azimuths smaller than $285^{\circ}$, line C of divergence points is clearly evident behind line A. Although it is located between line $\mathbf{A}$ and line $\mathbf{B}$, line $\mathrm{C}$ is not detected through most of the region at azimuths larger than $285^{\circ}$. A prominent but somewhat diffused divergent feature is located behind line $\mathrm{B}$. It appears that there is a quasi-periodic pattern parallel to $\mathrm{A}$ and $\mathrm{B}$. Lines $\mathrm{D}$ and $\mathrm{F}$ are not well defined and could be part of the same feature, whereas line $E$ is short and detached from the rest. The convergence points in front of line $\mathrm{A}$ are associated with a wave ahead of the gust front as will be shown later. Other inflection points close to the radar are associated with noises, ground clutter and turbulence at low altitude below $500 \mathrm{~m}$.

In order to understand the characteristics of inflection points, radial profiles of reflectivity,

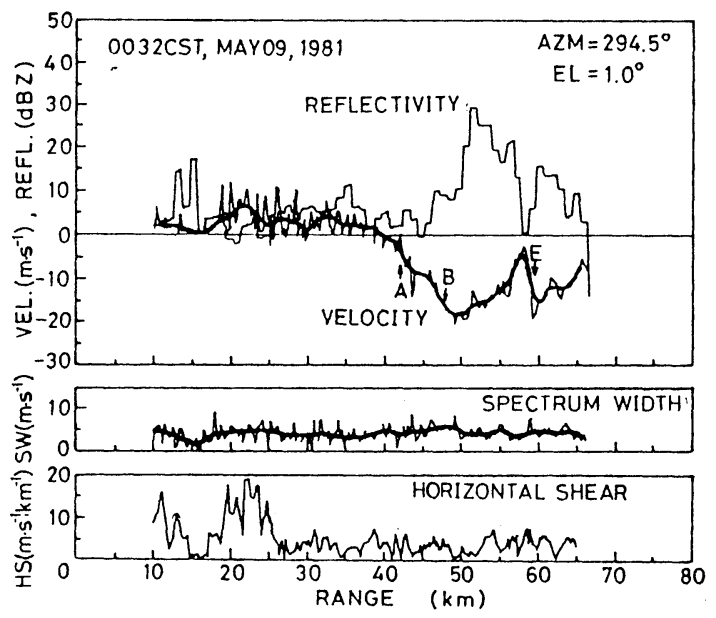

Fig. 4. Radial profiles of reflectivity, velocity, spectrum width and horizontal shear at the azimuth of $294.5^{\circ}$ at $0032 \mathrm{CST}$, May 9, 1981. Thick lines of velocity and spectrum width are nine points running averages. The arrows $\mathrm{A}, \mathrm{B}$ and $\mathrm{E}$ are the locations of inflection points of decreasing velocities. They correspond to the convergent inflection points $\mathrm{A}, \mathrm{B}$ and $E$ in Fig. 3. 
velocity, spectrum width and horizontal shear at the azimuth of $294.5^{\circ}$ are plotted in Fig. 4 . The radial at this azimuth is almost perpendicular to the gust front. The locations of $\mathrm{A}, \mathrm{B}$ and $\mathrm{E}$ shown by the arrows are inflection points of decreasing velocities. The inflection points of $A$ and $\mathrm{B}$, which are close to each other, suggest the dual signature of the front, though the front is usually expressed by a single line. In the range from 50 to $58 \mathrm{~km}$, inflection points of increasing velocities are identified. The location of the main gust front B (or A) is ahead of the largest reflectivity. No significant features in spectrum width profile is associated with the front, although the values have local maxima at the location of the main front (A and B). Similarly the horizontal shear field gives no clues as to the front's location. At ranges closer than $30 \mathrm{~km}$, data are affected by ground clutter as evidenced from erratic reflectivities and velocities that are close to zero. Beyond $30 \mathrm{~km}$ in range, the data

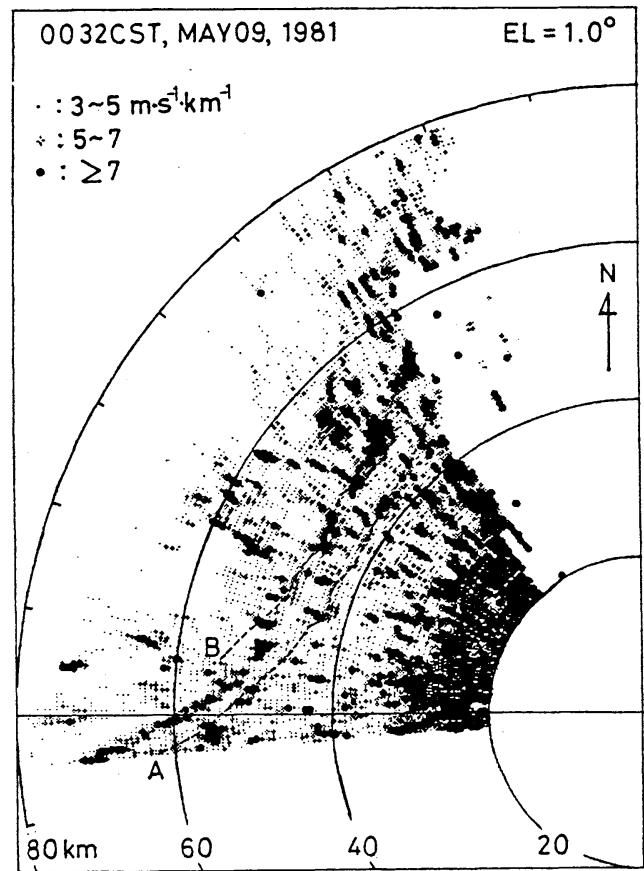

Fig. 5. Field of horizontal shear at 0032 CST, May 9, 1981. The magnitude of horizontal shear is shown by three symbols corresponding to $3-5,5-7$ and $\geq 7$ $\mathrm{m} \cdot \mathrm{s}^{-1} \cdot \mathrm{km}^{-1}$. Data are plotted every $0.7 \mathrm{~km}$ along radar radials. The lines of inflection points $(A$, and B) from Fig. 3 are superposed. appear normal.

In order to examine shear signature, the horizontal shear field for the scan of Fig. 3 is shown in Fig. 5. The lines of significant inflection points (A and B) are superposed in the plot. It is evident that the horizontal shear maxima occasionally coincide with the front position. Also large shear is spread over significant areas and is not easy to interpret. Large shear close to the radar $(<35 \mathrm{~km})$ is unreliable.

In Fig. 6 we show the spectrum width field for the scan of Fig. 3. Large spectrum widths are shown behind the maxima gradient lines of the fronts. Thus the maximum change is velocity precedes maximum turbulence. Local maxima of spectrum width occasionally coincide with the inflection points, and these may be produced by shear. It is obvious that the spectrum width field by itself is not sufficient to identify the frontal discontinuity.

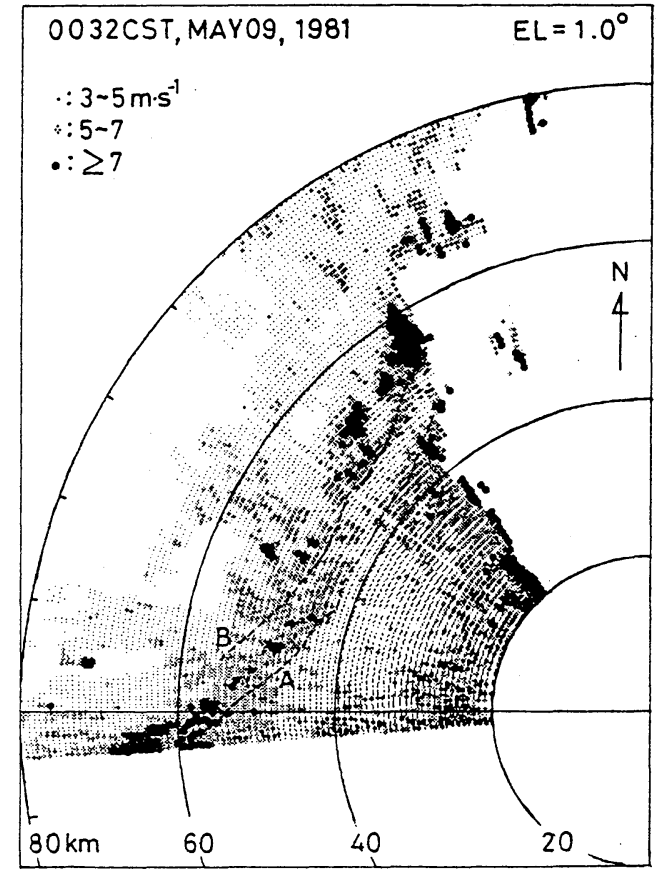

Fig. 6. Spectrum width field at 0032 CST, May 9, 1981. The magnitude of spectrum width is shown by three symbols corresponding to $3-5,5-7$ and $\geq 7 \mathrm{~m} \cdot \mathrm{s}^{-1}$. Data are plotted every $0.7 \mathrm{~km}$ along radar radial. The lines of inflection points ( $\mathrm{A}$ and $\mathrm{B}$ ) from Fig. 3 are superposed. 


\subsubsection{A wave pattern ahead of the gust front}

A quasi periodic pattern of inflection points (at 0020 CST) is evident to the southeast of the gust front (line $\mathrm{C}$ ) in Fig. 7. The spacing between two convergence lines ( $G$ and $I$ ) is about $5 \mathrm{~km}$. Between the two, a line of maximum divergence (inflection point $\mathrm{H}$ ) is obvious. In Fig. 7, a line of maximum divergence depicts prominently the gust front shape (line $\mathrm{C}$ ) whereas the convergence line is missing.

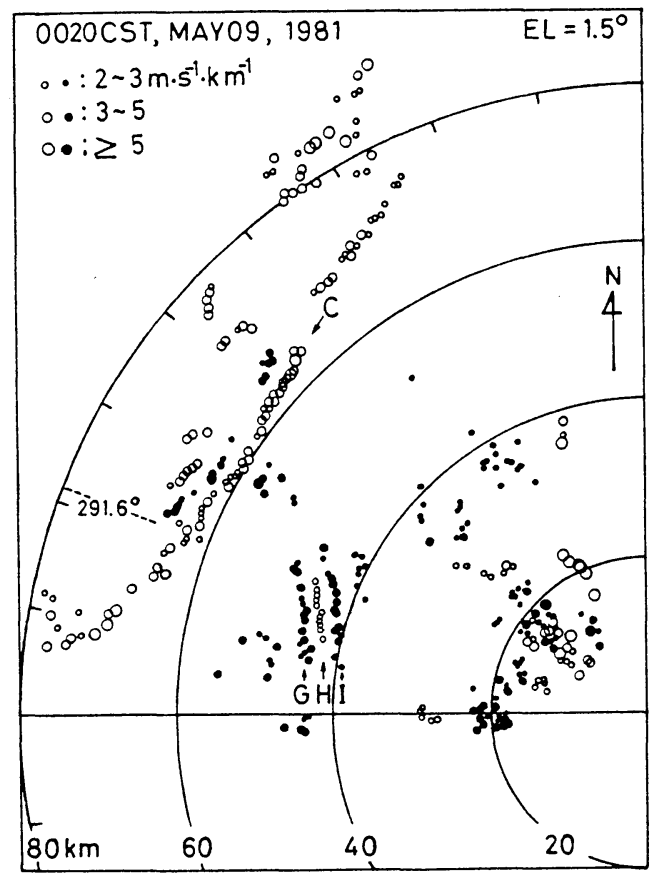

Fig. 7. The field of convergence $(\bullet)$ and divergence (o) maxima at $0020 \mathrm{CST}$, May 9, 1981. Elevation angle is $1.5^{\circ}$. Symbols are the same as in Fig. 3 .

Profiles of reflectivity, velocity, spectrum width and horizontal shear along a radial, which are almost perpendicular to the lines of inflection points $G$ and $I$, are shown in Fig. 8. Corresponding convergences are indicated by arrows; similar profiles are present in adjacent azimuths. Note that these patterns are not obvious in the profiles of reflectivity and spectrum width. Although data in the convergence zone of the main front are missing in Fig. 8, divergence lines (e.g. line C) are clearly identifiable.

Inflection points corresponding to convergence lines of the waves from four elevation

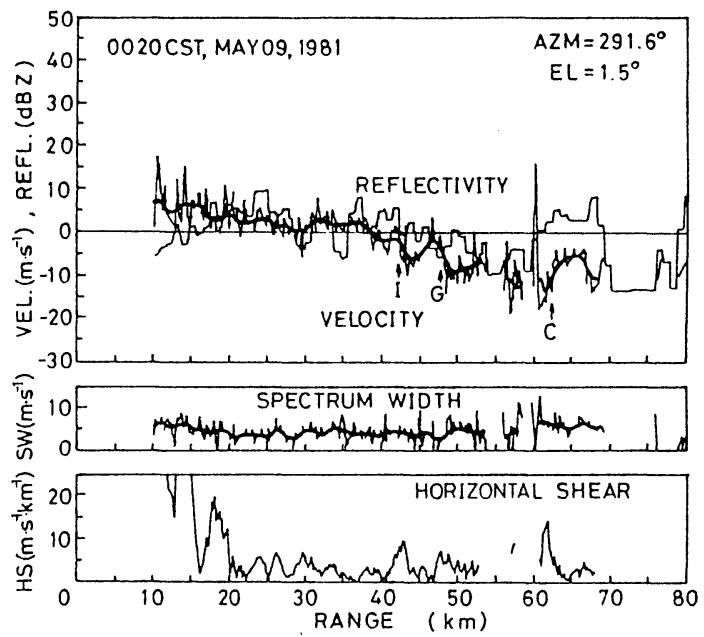

Fig. 8. Radial profiles of reflectivity, velocity, spectrum width and horizontal shear at the azimuth of $291.6^{\circ}$ at $0020 \mathrm{CST}$, May 9, 1981. Notations are the same as in Fig. 4. The arrows $G$ and $I$ are the locations of inflection points within decreasing velocities. They correspond to the convergence maxima $\mathrm{G}$ and $\mathrm{I}$ in Fig. 7.

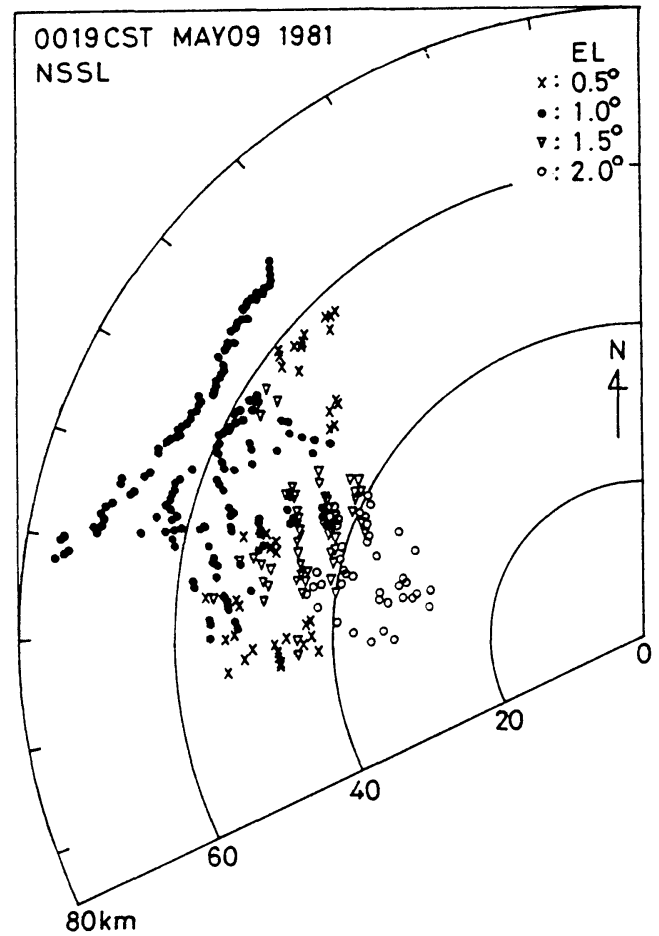

Fig. 9. The field of convergence inflection points at 0019 CST, May 9, 1981 from four elevation scans $\left(0.5^{\circ}, 1.0^{\circ}, 1.5^{\circ}\right.$ and $\left.2.0^{\circ}\right)$. The inflection points of the gust front are plotted for the elevation scan of $1.0^{\circ}$. 
scans $\left(0.5^{\circ}, 1.0^{\circ}, 1.5^{\circ}\right.$ and $\left.2.0^{\circ}\right)$ at $0019 \mathrm{CST}$ are projected on the $0.5^{\circ}$ elevation plane and plotted in Fig. 9. Inflection points from various elevations ahead of the main gust front partly overlap to form a clearly visible coherent structure. The spacing between waves varies from about $5 \mathrm{~km}$ at closer range (same as in Fig. 8) to about $3 \mathrm{~km}$ further out. The larger the elevation angle, the closer is the location of the plotted points to the radar. This suggests that the convergence points are almost at the same altitude. The ranges and the heights of the inflection points detected at three observation times and three elevation angles are shown in Fig. 10 where we see that the phenomenon is detectable between 900 and $1500 \mathrm{~m}$ above the ground.

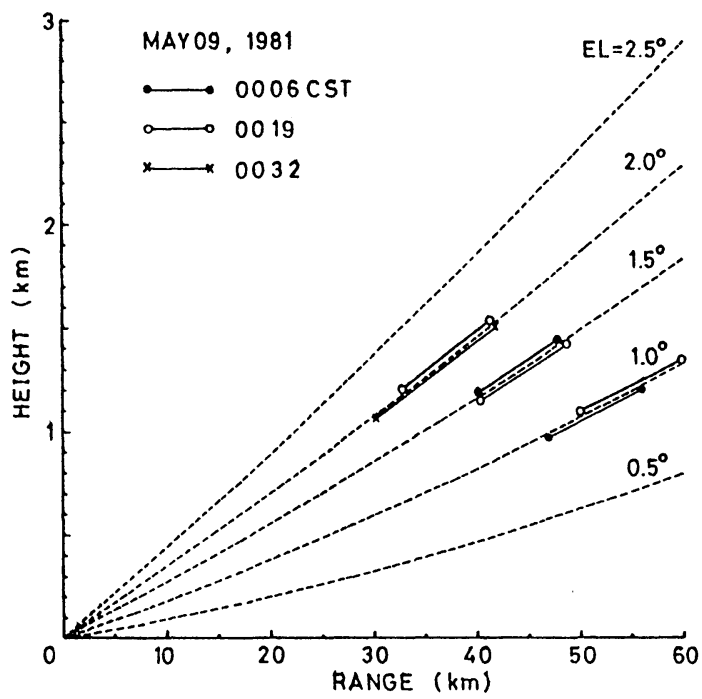

Fig. 10. The altitudes of the convergence maxima for three times and three elevations are shown by solid lines. Dashed curves show the heights of radar beam above the ground at each range.

\subsection{Gust front of April 13, 1981}

We examine next the fine structures of a gust front of April 13, 1981. In this case, the observations were made close to the radar and several scans at low elevation angles were obtained.

Figure 11 shows the field of inflection points at the elevation of $0.4^{\circ}$. As in the previous case, the front was propagating toward the radar. In this scan a line of inflection points. A depicting the

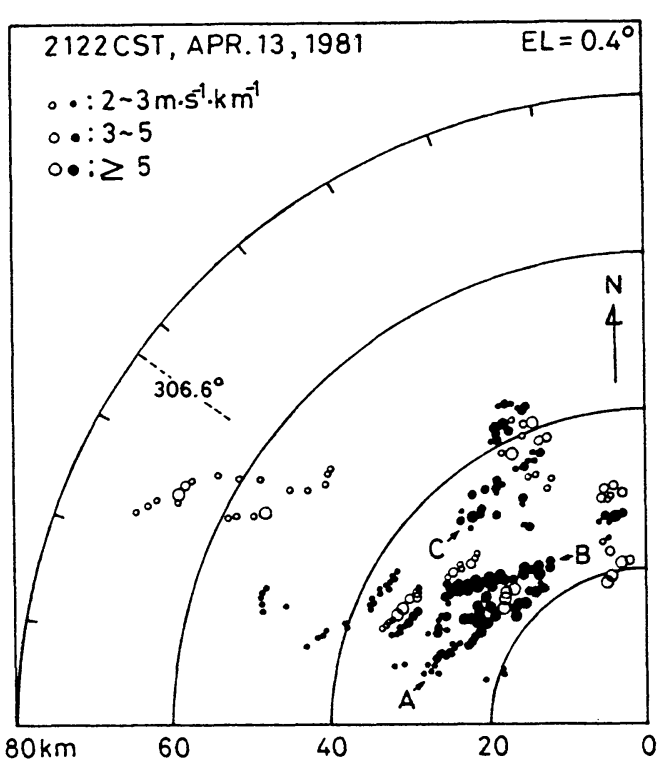

Fig. 11. The field of convergence inflection points $(\bullet)$ and divergence inflection points (o) at $2122 \mathrm{CST}$, April 13, 1981. The elevation angle is $0.4^{\circ}$. The symbols and notations are the same as in Fig. 3.

leading edge of the front is not as long, and pronounced as in higher scans. Behind it, another line of significant convergence (B) is discernible.

In order to examine the vertical continuity of gust front features, inflection points from higher elevation scans are plotted in Fig. 12. The main gust front exhibits good vertical continuity for five elevation scans. Branching of convergence lines (line B) is also evident at the elevation angle of $0.8^{\circ}$. Several signatures behind the front, like line $\mathrm{C}$ have vertical continuity. There are more significant inflection points at higher elevation scans than at lower scans. At the lowest elevation of $0.4^{\circ}$, there is a notable paucity of divergence maxima.

Figure 13 shows the radial profiles of reflectivity, velocity, spectrum width and horizontal shear from the elevation angle of $0.8^{\circ}$ and azimuth of $306.6^{\circ}$. Generally the leading edge exhibits strong convergence signature in the velocity profile similar to that of May 9, 1981. However, dual structure of the front and waves ahead of it, which are seen at the scan of May 9 , 1981, are not present. Large values of spectrum width and horizontal shear between 20 and 30 $\mathrm{km}$ are coincident with the main frontal dis- 


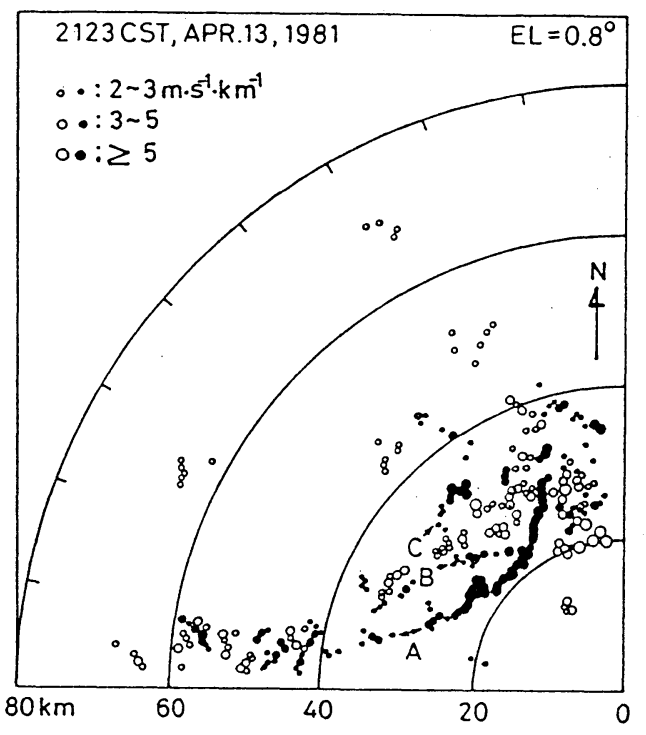

(a)

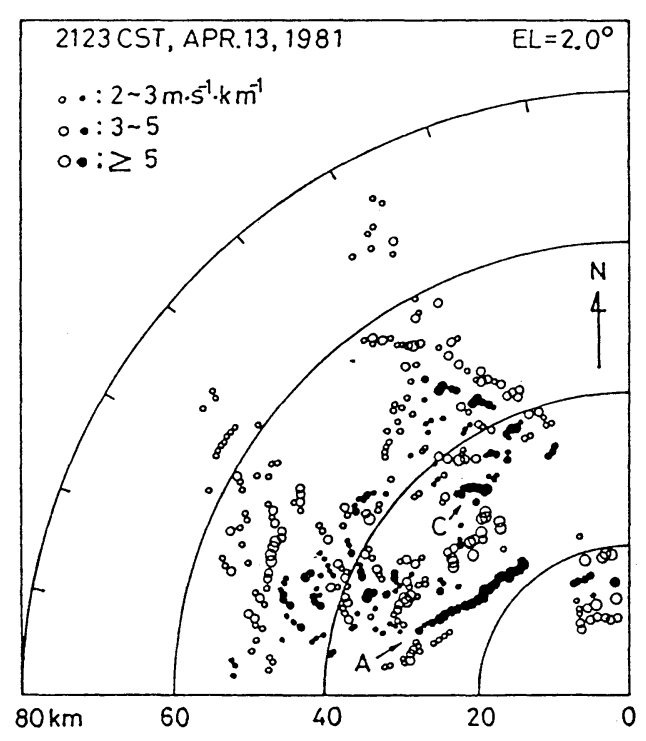

(c)

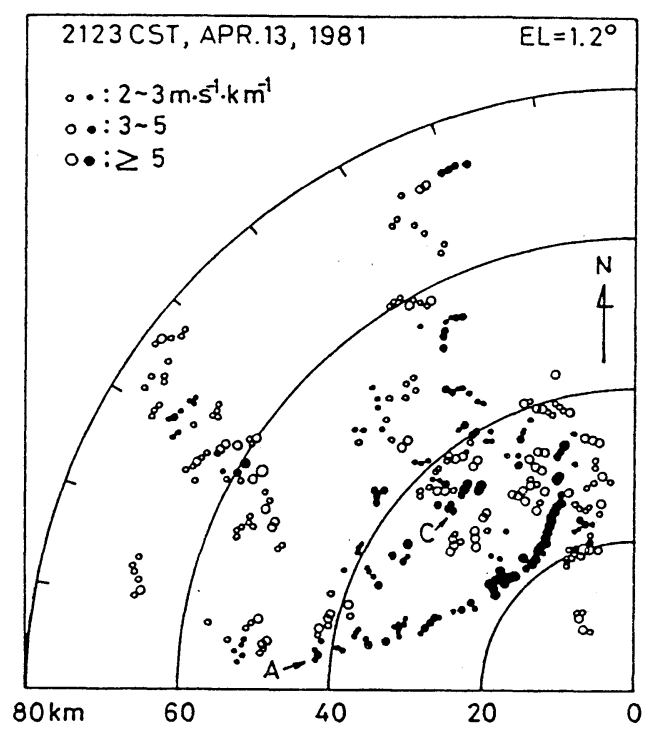

(b)

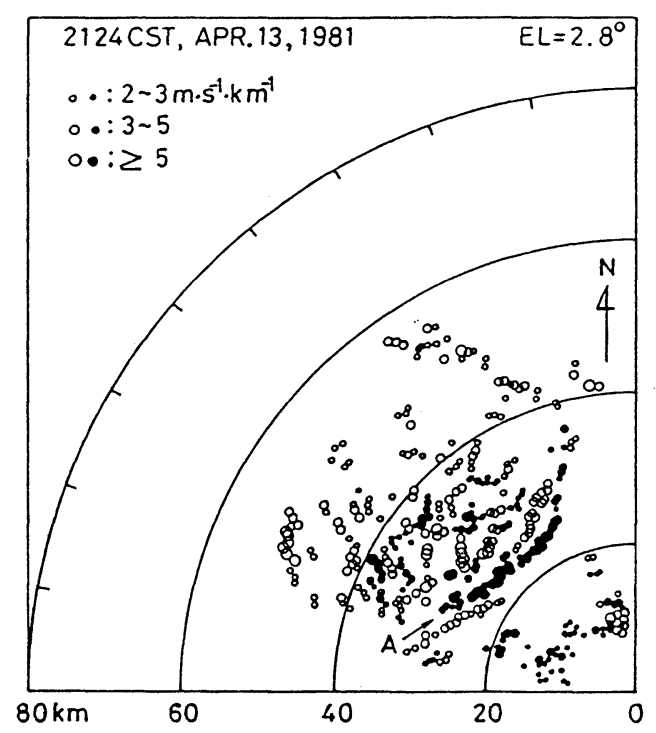

(d)

Fig. 12. Same as Fig. 11 except for the elevation angles: (a) $0.8^{\circ}$ (b) $1.2^{\circ}$, (c) $2.0^{\circ}$ and (d) $2.8^{\circ}$. 


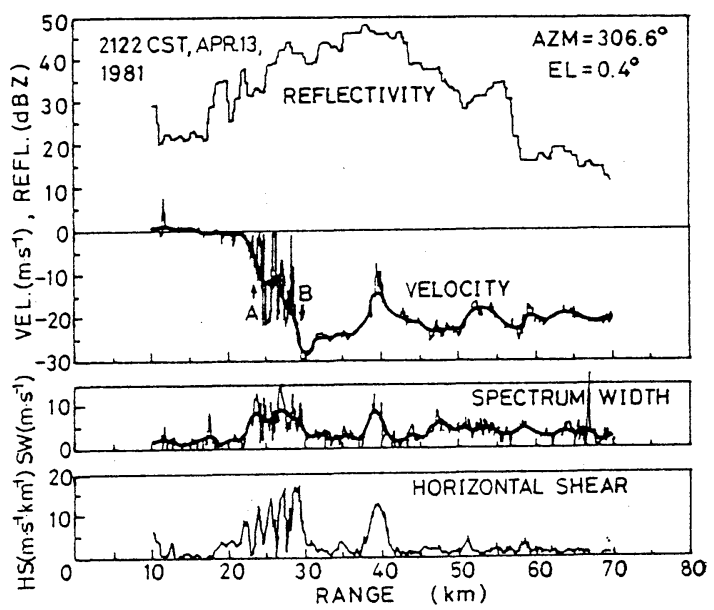

Fig. 13. Radial profiles of reflectivity, velocity, spectrum width and horizontal shear from the azimuth of $306.6^{\circ}$ at 2122 CST, April 13, 1981. Notations are the same as in Fig. 4. The elevation angle is $0.4^{\circ}$. The arrows $\mathrm{A}$ and $\mathrm{B}$ are the locations of inflection points within the decreasing velocities. They correspond to the convergent inflection points $A$ and $B$ in Fig. 11.

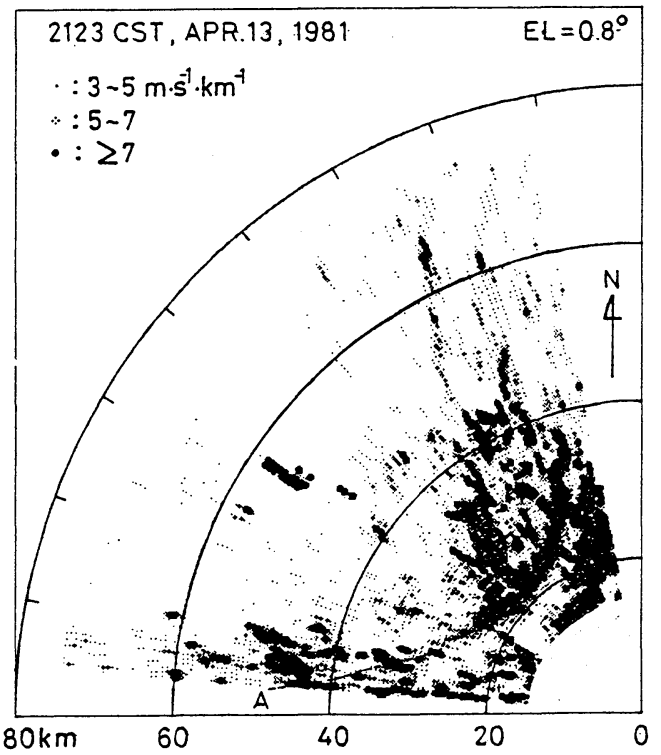

Fig. 14. Horizontal shear at 2123 CST, April 13, 1981. Notations and symbols are the same as in Fig. 5. The line of inflection points A from Fig. 11 is superposed. Data are plotted every $0.6 \mathrm{~km}$ along radials.

continuity. The inflection point $\mathrm{B}$ correspond to the branch of the main front $\mathrm{A}$ as shown in Fig. 11.

The horizontal shear field from the elevation

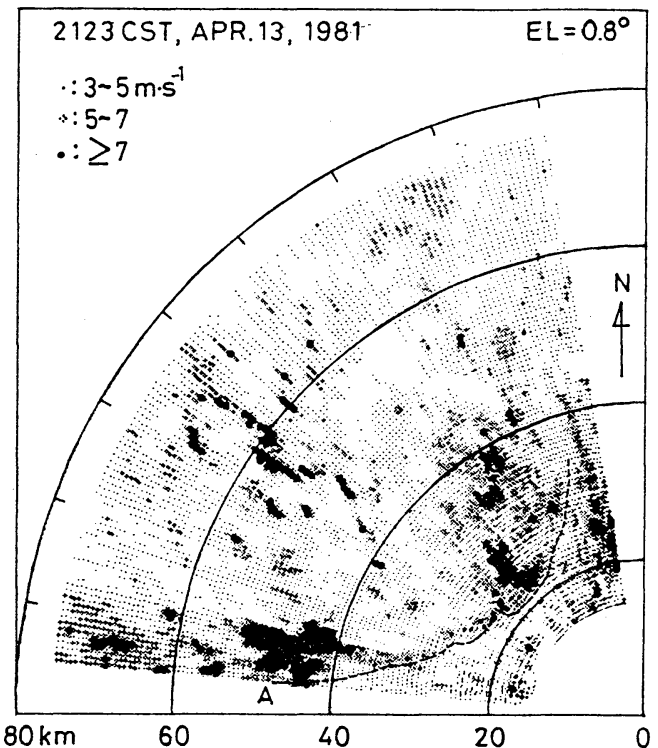

Fig. 15. Spectrum width field for the same scan as in Fig. 14. Notations and symbols are the same as Fig. 6. The line of inflection points A from Fig. 11 is superposed. Plotting interval is $0.6 \mathrm{~km}$ along radar radials.

of $0.8^{\circ}$ is shown in Fig. 14. The leading edge of the front is easily detected even in regions where it is parallel to the radials. Behind the front, a large coherent shear area persists; this area is populated by strong storm cells $(50 \mathrm{dBZ})$ that interact, each producing its own updraft and downdraft. Ahead of the front, weak signals and ground clutter are contaminating environmental flow measurements to produce significant shears.

Figure 15 shows the spectrum width field which is somewhat similar to the horizontal shear field. Again large spectrum widths follow the inflection point curve but are slightly behind it. Because of the abundance of significant widths $\left(>5 \mathrm{~m} \cdot \mathrm{s}^{-1}\right.$, it is doubtful that this field by itself could be used for positive identification of gust fronts.

\section{Discussion}

\subsection{Gust front feature}

\subsubsection{Dual structure of fronts}

Convergence maxima associated with a gust front lined up, over $60 \mathrm{~km}$, in the case of May 9 , 1981 as shown in Fig. 3 and 7. Between two convergence lines (A and B in Fig. 3) spaced 
several kilometers apart, a line of divergence was observed. The second convergence line B had larger gradient values than the first convergence line A. This implies that the main gust front is line B and up-downdraft circulation exists ahead of the main gust front. Fulton and Zrnic' (1986) have obtained vertical cross sections of this front in which waves with updraft and downdraft circulations are evident. They suggest that these are a part of an undular bore (analogous to bores in rivers) being generated by the gravity current. Our analysis has extracted the horizontal extent of this phenomenon.

The wave structure of the front is corroborated by the fact that areas of large spectrum widths are just behind the two lines of strongest gradients. According to simulations by Droegemier and Wilhelmson (1987) broad spectrum widths are expected to coincide with a turbulent area behind the front. Because the two lines had time continuity and significant velocity (line A and line B) we must conclude that the structure is stably evolving over several hours. Nocturnal inversion and the vertical profile of the shear may have contributed to this stability. To understand the formation mechanism of such phenomena, sounding data of temperature, dew point and wind from the early times in their evolution are needed.

The complicated structure and superposition of waves may be the reason for undulations seen in the detected gust by Uyeda and Zrnic' (1986). When gravity current and waves propagate into locally inhomogeneous media, their leading edge may continuously adjust to the local environment producing protrusions. This has been observed in laboratory experiments with water tanks (Simpson, 1972).

\subsubsection{Nose shape}

Vertical continuity of gust fronts was evident in both the May 9 and April 13, 1981 cases. In the case of April 13, the front was close to the radar and the elevation increments were $0.4^{\circ}$ for the first three scans, so that the tilt of the front could be observed. However, in the case of May 9 , the number of low elevation scans was not enough to check the tilt of the front.

In the case of April 13, the location of the gust front (depicted by maxima of velocity gradients) at the elevation of $0.4^{\circ}$ is one or two kilometers behind that of the front at the elevation of $0.8^{\circ}$. This may have been caused by friction near the ground and/or stagnation of air flow. The location of the front at the elevation angle of $2.8^{\circ}$ is a few kilometers back from the locations at the elevation angles of $0.8^{\circ}, 1.2^{\circ}$ and $2.0^{\circ}$. This is in accord with the nose-shaped vertical cross section of fronts proposed by Charba (1974) and others.

Velocity and horizontal shear are highly variable at the front location, and the spectrum width is very large suggesting presence of smaller scale turbulence (Fig. 13). Some regions of large spectrum widths persisted over longer times (10 min.) and extended over more than $10 \mathrm{~km}$ (line B in Fig. 11 and Fig. 15). These turbulent signatures around the nose region of front at low altitude might be interpreted as kinks (clefts) of fronts, as suggested by Simpson (1972) from laboratory experiments.

\subsection{Waves in the environmental flow ahead of the gust front}

The waves in the environmental flow ahead of the front (as shown in Fig. 9) are longitudinal rolls that are perpendicular to the mean shear axis (about $240^{\circ}$ ). We do not have independent measurements of wind profiles at the time of these waves; the closest time of a sounding is over six hours earlier (Fig. 16). We have therefore also shown on Fig. 16 wind speed and direction
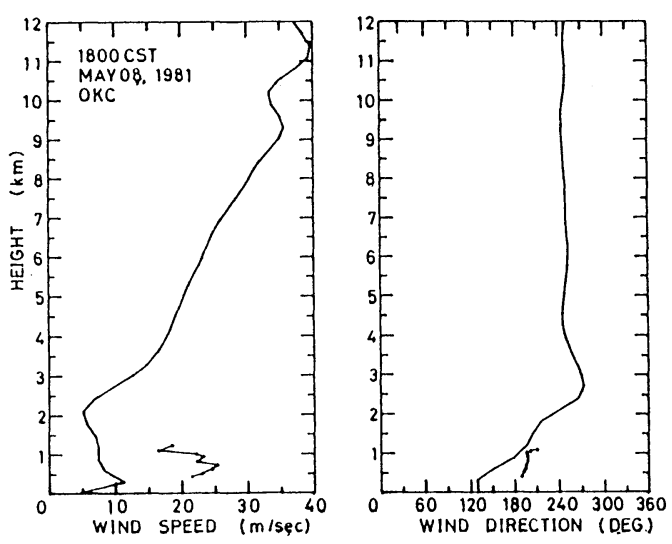

Fig. 16. Wind profiles of 1800 CST, May 8, 1981 at Oklahoma City. VAD winds at low altitude are plotted with solid circles and solid lines. 
obtained from VAD analysis. If we extrapolate the $V A D$ winds to higher altitudes we see that the winds and shears may have a strong component from about $240^{\circ}$ which is also the direction of wave propagation. The waves were confined to the stable layer which was close to 2 $\mathrm{km}$ deep; their origin and formation mechanisms are under consideration. Besides the wave signature itself, merging of the waves and the gust front makes the front structures more complicated as shown in Fig. 3.

\subsection{Features behind the main gust front}

Many rows of inflection points behind the main front, possibly secondary surges (superimposed outflow from convective cells), are extracted. However, their lengths are shorter (at most $20 \mathrm{~km}$ ). A few of these features had time continuity and vertical continuity, but were not evident at lower elevation scans. This vertical signature of inflection points behind the main front suggests that the density current at low altitude is dominant. In contrast to this, interaction of the lifted environmental flow with the denisty current may have produced persistent wavelike patterns. These are to be distinguished from the undular bore behind the main front that was in the process of being generated in the case of May 9. Most secondary surges are transient in nature and probably caused by subsequent down drafts and interactions of flows between different storms cells.

Rows of inflection points from May 9, 1981, believed to constitute an undular bore, are compared to tower (located $40 \mathrm{~km}$ north to the radar) data of the same event shown by Fulton and Zrnic' (1986). Three significant changes of pressure, potential temperature and wind about ten minutes apart are observed in Fig. 17. The second and third changes are not evident at the surface, although they are obvious at the $444 \mathrm{~m}$ level. In Fig. 3, the second convergence line B is well defined but the third is not clear between the azimuths of $280^{\circ}$ and $330^{\circ}$. At azimuths from $330^{\circ}$ to $350^{\circ}$, the third row of convergence is visible. Here, the main front (A) and (B) are not detected because the data are below threshold. After considering the propagation speed and tower location ( $40 \mathrm{~km}$ north of the radar) we conclude that the bore (i.e., three conver-

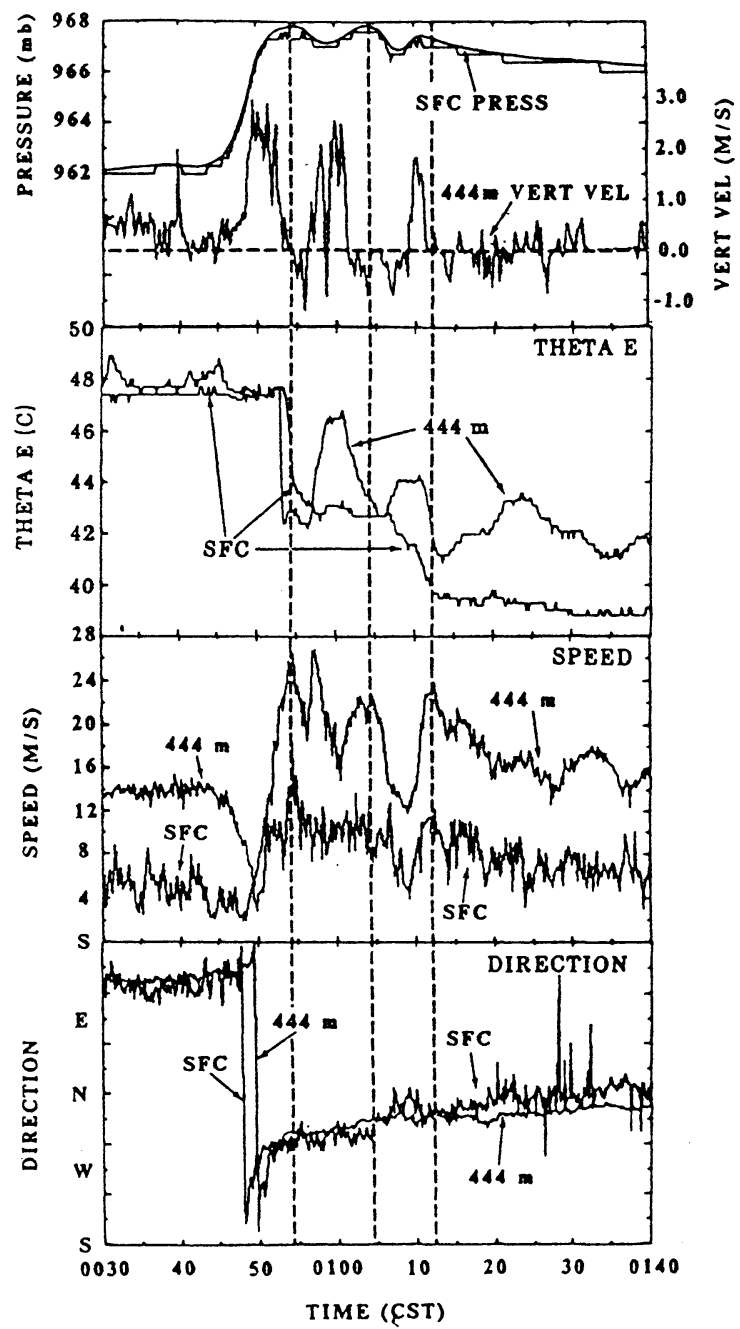

Fig. 17. Time series of variables at the surface and 444 $\mathrm{m}$ levels at the time of frontal/wave passage. (Fulton and Zrnic', 1986).

gence lines) would pass the tower from 0045 to 0115 CST which is in excellent agreement with tower observations. Still, even this tall tower cannot adequately observe features that the radar covers so well. This is mainly because the former offers point measurement and insufficient height to cover the total depth of the inflow.

\section{Conclusion}

Several volume scans of Doppler radar data have been used to analyze two gust fronts that occurred in 1981 in central Oklahoma, U.S.A. Our analysis examines fields of velocity inflection points (maxima of radial velocity gradients), 
fields of Doppler spectrum width and fields of horizontal shear (of radial velocities).

Our study confirms that a primary signature of gust fronts is to be sought among the radial gradients of Doppler radar velocity data (Uyeda and Zrnic', 1986). Horizontal shear of radial velocities and Doppler spectrum width can provide supporting information but by themselves are not unique indicators.

Because of its ability to clearly depict maxima of radial convergence (or divergence), the method of extraction of inflection points of Doppler velocity has physical appeal in classifying gust fronts. That is a reason why features such as waves, undular bores and gust fronts are detectable if they are not aligned parallel to radar radials. But even in favorable situations, detection depends heavily on thresholds of velocity gradient and other factors.

If thresholds are set low (as in our analysis), a multitude of features subsidiary to the main ones are detected. These are transient and therefore would not be suitable for tracking.

Inflection point analysis revealed the true extent of an undular bore whose presence was suggested by Fulton's (1987) analysis of the May 9, 1981 case. Also, the presence of waves was evident ahead of the bore. To adequately explain both of these phenomena, contemporaneous supporting information from rewinsondes, tower, surface stations, and other radar measurables is needed.

\section{Acknowledgements}

The authors express their thanks to Dr. Doviak, National Severe Storms Laboratory, NOAA, for his suggestions and encouragement through this work. One of the authors, Uyeda, is grateful to Prof. K. Kikuchi, Hokkaido University, for his support of this work. The authors also appreciate the advice of Mrs. Y. Gal-Chen, CIMMS, Mr. H. Ohokura, National Research Center for Disaster Prevention and Dr. H. Asuma, Hokkaido University, concerning reading of data tapes.

\section{References}

Browning, R.B. and R. Wexler, 1982: A determination of kinematic properties of a Wind field using Doppler radar. J. Appl. Meteor., 7, 105-113.
Charba, J., 1974: Application of a gravity current model to analysis of squall line gust front. Mon. Wea. Rev., 102, 140-156.

Doviak, R.J. and D.S. Zrnic', 1984: Doppler radar and weather observations. Academic Press, FL, $458 \mathrm{pp}$.

Droegemeier, K.K. and R.B. Wilhelmson, 1985a: Three dimensional numerical modeling of convection produced by interacting thunderstorm outflows, Part $\mathbf{I}$ : Control simulation and low-level moisture variations. J. Atmos. Sci., 42, 2381-3403.

- and 1985b: Three dimensional numerical modeling of convection produced by interacting thunderstorm outflows, Part II: Variations in vertical wind shear. J. Atmos. Sci., 42, 2404-2414.

Fulton, R., 1987: Observations of interactions of $a$ nocturnal thunderstorm outflow with a stable environment. M.S. Thesis, University of Oklahoma, $147 \mathrm{pp}$.

and D.S. Zrnic', 1986: Doppler radar and in-situ measurements of a nocturnal thunderstorm gust front. Preprints, 23rd Conf. on Radar Meteoro$\log y, \mathrm{~J} 85-\mathrm{J} 88$.

Goff, R.C., 1985: Thunderstorm outflow kinematics and dynamics, NOAA Tech. Memo ERL TM-NSSL, No. 75,63 pp.

Holle, R.L., and M.W. Maier, 1980: Tornado formation from downdraft interaction in the FACE mesonetwork. Mon. Wea. Rev., 108, 1010-1028.

Klingle, D.L., 1985: A gustfront case studies handbook. DOT/FAA/PM-84/15 108 pp.

Miller, L.J., and J.C. Fankhauser, 1983: Radar echo structure, air motion and hail formation in a large stationary multi-cellular thunderstorm. J. Atmos. Sci., 40, 2399-2418.

Mueller, C.A. and R.E. Carbone, 1987: Dynamics of a thunderstorm outflow. J. Atmos. Sci.. 44, 18791898.

Peterson, R.E., 1984: A triple-Doppler radar analysis of a discretely propagating multicell convection storm. J. Atmos. Sci., 41, 2973-2990.

Purdom, J.F.W., 1982: Subjective interpretation of geostationary satellite data for nowcasting. Nowcasting, 'Eith Browning, Ed., Academic Press, 149-156.

Simpson, J.E., 1969: A comparison between laboratory and atmospheric density currents. Quart. J. Roy. Met. Soc., 95, 758-763.

, 1972: Effects of the lower boundary on the head of a gravity current. Fluid Mech., 53, 759-768.

and R.E. Britter, 1980: A laboratory model of an atmospheric mesofront. Quart. J. Roy. Meteor. Soc., 106, 485-500.

Uyeda, H. and D.S. Zrnic', 1986: Automatic detection of gust fronts. J. Atmos. Oceanic. Technol., 3, 36-50.

Weaver, J.F. and F.P. Nelson, 1982: Multiscale aspects of thunderstorm gust fronts and their effects on subsequent storm development. Mon. Wea. Rev., 
110, 707-718.

Wilhelmson, R.B., and C.S. Chen, 1982: A simulation of the development of successive cells along a cold outflow boundary. J. Atmos. Sci, 39, 1466-1483.
Zrnic' and Lee, 1983: Investigation of the detectability and lifetime of gust fronts and other weather hazards to aviation, FAA Rep. No. DOT/FAA/PM-83/33.

\title{
1 台のドップラーレーダーのデータ解析による突風前線の微細構造
}

\author{
上田博
}

(北海道大学理学部)

\section{Dusan S. Zrnic'}

（米国国立中小規模擾乱研究所）

ドップラーレーダーの速度成分のデータを用いて雷雲に伴う突風前線の微細構造を調べた。速度成分 の変曲点の面的分布（アンテナの水平回転による）をスペクトル幅及び水平シアーと同時に調べた。解 析は，米国オクラホマ州に抒ける，1981年 5 月 9 日と 4 月13日の 2 例について行った。前者の例では， $3 つ$ つ不連続な波状列をもつ，発達した波が識別された。このらちの 2 つ波は60kn程度の長さをもつ 変曲点の列であったが, 第 3 の波は識別限界すれすれであった。解析した 2 例とも, 主な突風前線の後 方の 2 次的な構造は, 長さ $20 \mathrm{~km}$ 以下で継続時間の短いものであった。注意深い解析により，低高度で は, 大さなスペクトル幅と大さな水平シアーをもつ領域は主な変曲点列のすぐ後方にあることがわかっ た。しかし，対応する変曲点列をもたない，大きなスペクトル幅や大きな水平シアーをもつ領域も存在 した。このように，スペクトル幅や大さな水平シアーの值のみから突風前線の位置を検出することは困 難である。変曲点列は, 突風前線の位置を示すだけでなく, 種々の波動の位置の良い指標であることが わかった。さらに，突風前線前方の気流中にみられたこのよらな波のパターンについても議論する。 